\title{
AN INTERESTING NEW SPECIES OF BACCHARIS (ASTERACEAE: ASTEREAE) FROM MINAS GERAIS, BRAZIL ${ }^{1}$
}

\author{
LEONARDO PAZ DEBLE ${ }^{2}$ ANABELA SILVEIRA DE OLIVEIRA DEBLE ${ }^{3}$
}

\section{RESUMO}

[Uma curiosa nova espécie de Baccharis (Asteraceae: Astereae) de Minas Gerais, Brasil].

Uma nova espécie, nomeada Baccharis variabiliflora é descrita e ilustrada, e tem suas afinidades taxonômicas discutidas. A nova espécie é facilmente separada das demais espécies que compõem o gênero pelos seus capítulos com flores centrais estaminadas, flores marginais pistiladas e entre essas um grupo de flores não funcionais. Baccharis variabiliflora ocorre no Brasil central, aparentemente endêmica de campos úmidos e cerrados do estado de Minas Gerais.

Palavras Chave: Baccharidinae, Cerrado, Cylindricae, Taxonomia.

\section{ABSTRACT}

A new species, named Baccharis variabiliflora is described and illustrated and has their taxonomic affinities discussed. The new species is easy segregate of all species of the genus by its capitula with central staminate flowers, marginal pistillate flowers and between one and other a group of non functional flowers. Baccharis variabiliflora occurs in Central Brazil, seemingly endemic to the wet grasslands and cerrados of Minas Gerais state.

Key words: Baccharidinae, Cerrado, Cylindricae, Taxonomy.

\section{INTRODUCTION}

During the revision of Herbarium, a voucher specimen deposited at HB herbarium was studied by us. This material was collected by Edmundo Pereira, Guido Pabst and Gert Hatschbach in the year 1964, in the road to Ouro Negro, Minas Gerais state, and additional collection of this taxon did not are known. This exsiccate was recognized by us as a new species in 2006, but in view of the single material known, we were expecting new collections until this work to describe it. Unfortunately, new collections are unknown and based in the single collection above mentioned is described and illustrated below Baccharis variabiliflora, a new species belonging to section Cylindricae Heering.

1 Recebido em 10-04-2013 e aceito para publicação em 27-05-2013.

1 Dr. Professor do Curso de Ciências da Natureza, UNIPAMPA(Dom Pedrito-RS). deble.biol@gmail.com

2 Dra. Professora do Curso de Tecnologia em Gestão Ambiental, URCAMP (Dom Pedrito-RS). anabela.biol@gmail.com

\section{RESULTS AND DISCUSSIONS}

Baccharis variabiliflora Deble \& A. S. Oliveira, sp. nov. (Figure 1)

Species nova ad sectioni Cylindricae pertinens, a ceteris species capitulis cum 3-6 flores marginales pistillatis, 1 -3 flores centrales staminatis et 8-11 flores neutrae inter centrales et marginales dispositis conjunctim praesentibus differt.

Typus: BRAZIL. Minas Gerais: Ouro Preto "Estr. p/Ouro Preto km. 48, esperança, arb. unicaule, fl. creme" 13 September 1964, E. Pereira 9231, G. Pabst 8232 \& G. Hatschbach 11562 (holotypus HB!, isotypus MBM).

Subshrubs 0.8-1.2 m high (with xylopodium?). Stem solitary, erect, branching only in the capitulescence or unbranched. Leaves appressed at the stem, oblong or oblongspatulate, $15-35 \mathrm{~mm} \times 2-6 \mathrm{~mm}$, alternate, sessile, concolorous, 3-veined, margin entire, or minutely serrate, apex obtuse or rounded, mucronate, base attenuate; leaf blades chartaceous, reddish brown, punctuate glandular, seemingly glabrous with tufted trichomes of flagellate and biseriate trichomes scattered. 


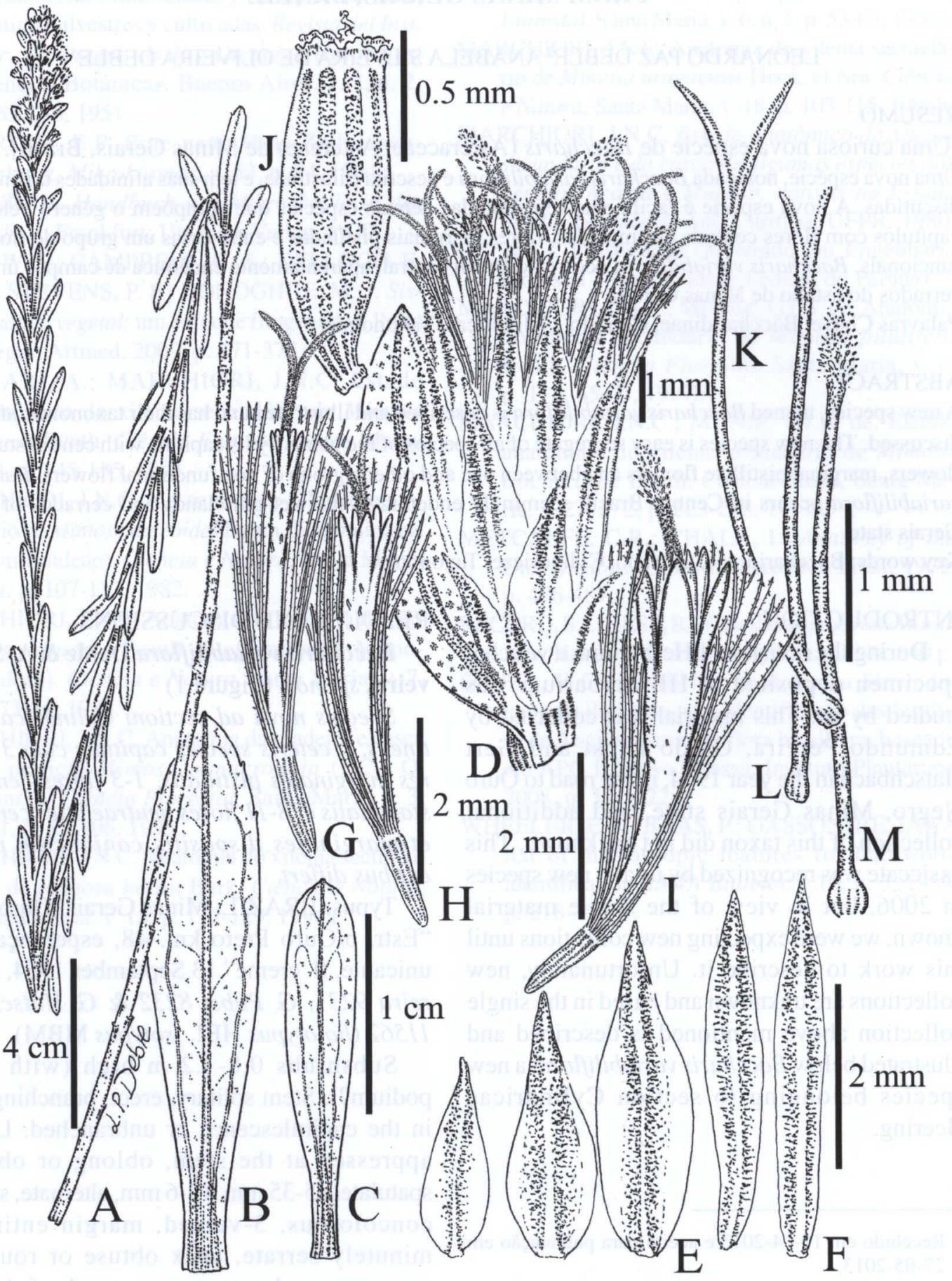

FIGURE 1 - Baccharis variabiliflora. A. Plant. B. Basal leaf. C. Distal leaf. D. Capitulum. E-F. Phyllaries. E. Outermost phyllaries. F. Innermost phyllaries. G. Pistillate flower. H. Non functional flower. I. Staminate flower. J. Cypsela. K. Style of pistillate flower. L. Style of non functional flower. M. Style of staminate flower (A-M, from the holotype). 
Capitula solitary, in leafy axils, 6-7 $\mathrm{mm} \times 4-5$ $\mathrm{mm}$; involucre narrowly campanulate, $5-6 \mathrm{~mm}$ $\times 3-4 \mathrm{~mm}$; flowers 16-20; marginal flowers 36 , pistillate; central flowers 1-3, seemingly perfect, but functionally staminate flowers; between one and other 8-11 non functional flowers. Phyllaries in 3-4 series, apex acute acuminate, often orange-darker in the distal third, margins membranous, hyalines, fimbriate, dorsum with glandular trichomes. Outermost phyllaries lanceolate, $1.7-3 \mathrm{~mm} \times 0.9-1.2 \mathrm{~mm}$; innermost phyllaries lanceolate or ellipticlanceolate, 3-3.5 $\mathrm{mm} \times 0.8-1 \mathrm{~mm}$. Receptacle conical, alveolate and with receptacular fimbrils. Pistillate corolla tubular-filiform, 3-3.8 mm long, with few glandular trichomes scattered, apically 5-dentate, teeth up to $0.7 \mathrm{~mm}$ long. Style exceeding the corolla, 4-4.4 mm long; branches linear-lanceolate, 0.7-0.8 mm long. Pappus of 34-46 bristles, $2.4-4.6 \mathrm{~mm}$ long, uniseriate, rigid, partially fused in a basal ring, deciduous, not or slightly elongated at cypsela maturity, yellowish. Cypsela brown, oblong, 1.2-1.5 mm long, epidermis folded, laterally slightly compressed, with 8-10 longitudinal ribs. Non functional flowers corolla 3.4-4 $\mathrm{mm}$ long, apically 5dentate, teeth up to $1 \mathrm{~mm}$ long. Style similar to the pistillate flowers, but with few sweeping trichomes in the medial portion of the branches. Staminate flowers corolla 4-4.2 mm long, apically 5-dentate, teeth up to $1.2 \mathrm{~mm}$ long. Anthers $0.9-1.1 \mathrm{~mm}$ long. Style not or slightly exceeding the corolla, 4-4.5 mm long; style branches with ca. $0.2 \mathrm{~mm}$ long, attached or free apically. Pappus of 31-49 bristles, 2.5-4.6 mm long, rigid, deciduous, ends in two acute papillae, yellowish. Cypsela abortive, obconical, ca. $1 \mathrm{~mm}$ long.
Distribution and Habitat: Baccharis variabiliflora occurs in Central Brazil, seemingly endemic to the wet grasslands and cerrados of Minas Gerais state.

Etymology: From the Latin variabilis meaning variable and florus that mean flower and refers to capitulum containing pistillate flowers, non functional flowers and staminate flowers.

Comments: Baccharis variabiliflora by its capitula with 1-3 central staminate flowers, surrounded by $8-11$ non functional flowers and 3-6 marginal pistillate flowers is unique within genus. Despite this morphological peculiarity, the new species belongs to section Cylindricae based in the following attributes: cylindrical shape of capitula, cypselae 8-10 ribbed, with folded epidermis, 2-seriate and deciduous pappus, and pistillate corolla at the apex 5dentate (Cuatrecasas, 1967; Giuliano, 2001; Giuliano, 2005). Unfortunately did not were observed staminate capitula, but the presence of 1-3 staminate central flowers makes doubt if the species is really a dioecious species.

Conservation Status: Insufficient data availed.

\section{REFERENCES}

CUATRECASAS, J. Revisión de las especies Colombianas del género Baccharis. Revista de la Academia Colombiana de Ciencias Exactas, Físicas y Naturales, Bogotá, v. 13, n. 49, p. 5102.

GIULIANO, D. A. Clasificación infragenérica de las espécies argentinas de Baccharis (Asteraceae, Astereae). Darwiniana, San Isidro, v. 39, n. 12, p. 131-154. 2001.

GIULIANO, D. A. New infragenera in Baccharis (Asteraceae, Astereae). Novon, Missouri, v. 15, n. 4 , p. 534-541. 2005. 